\title{
Tensile Strength of Orbital Welded Mild Steel Tubes with Dissimilar Thickness
}

\author{
N. I. S. Hussein, M. N. Ayof, and S. Nordin
}

\begin{abstract}
Lightweight trend leads to new trend of welding in which optimizing tubes or pipes thicknesses due to its respective workloads. Thinner tube can be used in parts with low working loads and thicker tube for high working loads parts. In order to obtain a good weld, controlling the process parameters such as welding current and welding speed become very crucial as it significantly influences the mechanical properties. Thus, the purpose of this study is to investigate the process-properties relationship of welded mild steel tube of dissimilar thickness by using Metal Inert Gas (MIG) orbital welding. The effects of weld current and jig rotational speed to the tensile properties of welded mild steel tubes were studied. MIG welding was used to weld $26.70 \mathrm{~mm}$ diameter of mild steel tubes, which has dissimilar inner diameter of $2.87 \mathrm{~mm}$ and $3.90 \mathrm{~mm}$, respectively. The mechanical properties were tested using Universal Tensile Machine (UTM) Instron 8802 model. Design of Experiment (DoE) was used to design the experiment as well as to analyze the data. It was found out that, tensile properties of welded tubes increase with increasing of welding current between 60 and $80 \mathrm{~A}$ On the other hand, increasing in jig rotational speed between 40 and $50 \mathrm{rpm}$ decreases the tensile properties of the welded tubes. Empirical mathematical model was generated and verified.
\end{abstract}

Index Terms-Mild steel, orbital welding, metal inert gas welding, tensile strength and empirical mathematical modeling.

\section{INTRODUCTION}

Lightweight automobiles become trend nowadays which can profit manufacturers by saving cost and indirectly makes cars eco-friendlier by reduces the emissions of $\mathrm{CO}_{2}$ [1]. ThyssenKrupp [1] and WISCO [2] found that varying wall thickness of tube used in exhaust system or in chassis depending on their workloads can help to reduce overall weight of the car. Tailored orbital welding is a technology that has capability of joining up to five tubes together and each individual tube can be of different materials, diameters, wall thickness and even coatings [3]. One of the success stories of tailored orbital welding by ThyssenKrupp [1] is they has successfully developed a tailored orbital alternative for a rear seat back reinforcement made from conventional tube. The structure is made from a tube of uniform wall thickness, which determined by the highest loads occurring in the part. The new solution successfully reduces weight by around a kilogram

Manuscript received March 15, 2015; revised July 10, 2015. This work was supported in part by the Ministry of Education Malaysia under Grant RAGS/2012/UTEM/TK01/4 B00015.

N. I. S. Hussein and M. N. Ayof are with the Faculty of Manufacturing Engineering, Universiti Teknikal Malaysia Melaka (UTeM), 76100 Durian Tunggal, Malacca, Malaysia (e-mail: izan@utem.edu.my, nizam@utem.edu.my).

S. Nordin was with the Faculty of Manufacturing Engineering, UTeM, Malacca, Malaysia (e-mail: safuranordin@gmail.com). because the part made form a tailored orbital of different wall thickness. In other cases, tailored orbital for shock absorber reservoir tubes claimed weight reductions of up to $30 \%$ [3].

There are several heat sources available for joining pipe and those that widely used in orbital welding includes shielded metal arc welding (SMAW) and MIG processes. Arunkumar et al. [4] and Olawale et al. [5] found that parameters of welding process give great influences to mechanical behaviour of the welded tubes.

Singh et al. [6] have done a study about effect of welding current to the welding depth of penetration of $5 \mathrm{~mm}$ thickness mild steel by using SMAW welding process. They found that the penetration depth increased in increasing of welding current. Lian [7] and Karadeniz et al. [8] found that when the weld current is increased, the depth of penetration will also increase. MIG welding was used in their experiment but with different materials. Lian [7] used $2.5 \mathrm{~mm}$ thickness of stainless steel tube while Karadeniz used the same thickness of Erdemir 6842 steel. Using ST-37 mild steel plates of 25 $\mathrm{mm}$ thickness as weld material and MIG welding as heat source, Bahman and Alialhosseini [9] founds that the higher the weld current will caused the decreasing in mechanical properties of weld metal.

In regards to dissimilar thickness tubes, Alenius et al. [10] found that thicker thickness will give higher fatigue strength of welded structure when non-stainless steel sheets of $1.5 \mathrm{~mm}$ and $0.7 \mathrm{~mm}$ thickness were weld by using spot welding. Darwish and Samhan [11] also state that thinner part of joint have higher stress concentration than in thicker part.

This study investigates the effect of MIG welding current and jig rotational speed to the tensile strength of mild steel tubes in which joint at dissimilar inner diameter. Empirical mathematical model of the ultimate tensile strength is then developed and optimum set of parameters for these orbital welding processes are then suggested.

\section{EXPERIMENTAL METHODS}

\section{A. Material Preparation}

Mild steel, which also known as low carbon steel contains fine grain with ferrite phase structure. Low carbon steel has good mechanical properties as it has soft metric ferrite with good ductility. Taking the average size and commonly used of mild steel in go-kart chassis tube, mild steel pipes of 26.70 mm diameter having thicknesses of $2.87 \mathrm{~mm}$ and $3.90 \mathrm{~mm}$ are used in this experiment. The pipes are first cut into $112.5 \mathrm{~mm}$ length each. There will be 24 specimens in total, 12 pipes of $2.87 \mathrm{~mm}$ thickness and another 12 pipes of $3.90 \mathrm{~mm}$ thickness, for 12 sets of experiments. The tubes were first to be cut into 
smaller tubes by using abrasive saw. The tubes were cut into $110 \mathrm{~mm}$ long each using disc cutter machine. The tubes were then cleaned by removing burr and rust. Fig. 1 shows the schematic diagram of dissimilar thickness tubes joint.

\section{B. Welding Processes}

The mild steel tubes were clamped at the rotating jig and the MIG welding operations were performed by Fronius TS 4000C MIG welding machine with VR 4000 model of wire feeding system. Torch angle was set to $60^{\circ}$. Wire electrode of mild steel material with $1.0 \mathrm{~mm}$ diameter was used as filler material and argon was used as shielding gas. Anyeke welding positioner of APL-100 model was used for clamping pipes in $1 \mathrm{G}$ position as shown in Fig. 2. Jig rotates the steel tube while nozzle static in place during the welding process, while performing the orbital welding process. The available speed for the jig is between 1 to $100 \mathrm{rpm}$.

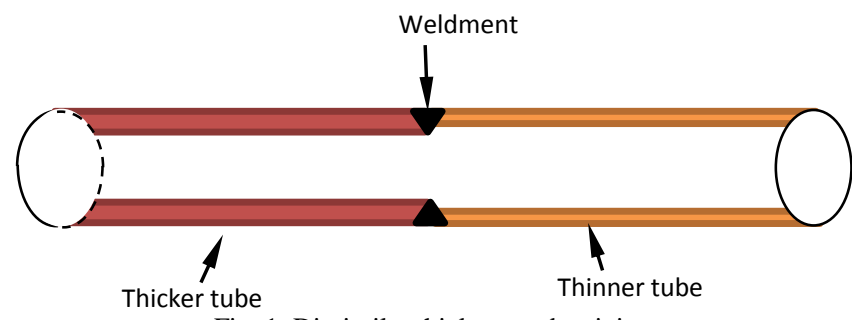

Fig. 1. Dissimilar thickness tubes joint.

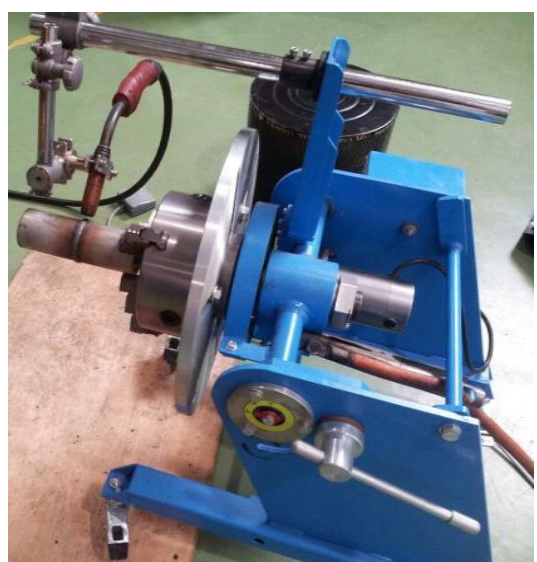

Fig. 2. Welding positioner holds the pipes at $1 \mathrm{G}$ position.

\section{Design of Experiment}

Dependent welding parameters for this study were welding current and jig rotational speed. Welding current was set for low and high level at $60 \mathrm{~A}$ and $80 \mathrm{~A}$, respectively. While for jig rotational speed, $40 \mathrm{rpm}$ and $50 \mathrm{rpm}$ were set as low and high level, respectively (refer to Table I). By using full factorial formula, number of tests is $y^{x}$ where $y$ is number of conditions and $x$ is number of factors. Hence, number of tests for this experiment was $2^{2}$ in which equals to 4 . The experiment was replicated thrice so the number of tests was 12 in total. By setting the welding current, the welding voltage and wire feeding speed were automatically calculated by machine are shown in Table II.

TABLE I: WELDING PARAMETERS AND THEIR VARIABLES

\begin{tabular}{|c|c|c|c|}
\hline Welding Parameter & Unit & Low Level (-1) & High Level (+1) \\
\hline Welding current & $\mathrm{A}$ & 60 & 80 \\
\hline Jig rotational speed & $\mathrm{rpm}$ & 40 & 50 \\
\hline
\end{tabular}

TABLE II: WeLding Voltage AND WIRE FEEDING SPEED Automatically SET BY THE MACHINE IN REFERENCE TO THE WELDING CURRENT

\begin{tabular}{|c|c|c|}
\hline $\begin{array}{c}\text { Welding Current } \\
(\mathrm{A})\end{array}$ & $\begin{array}{c}\text { Welding Voltage } \\
(\mathrm{V})\end{array}$ & $\begin{array}{c}\text { Wire Feeding Speed } \\
(\mathrm{m} / \mathrm{min})\end{array}$ \\
\hline 60 & 17.6 & 2.0 \\
\hline 80 & 17.9 & 2.4 \\
\hline
\end{tabular}

\section{Tensile Testing}

Universal Tensile Testing Instron 8802 model was used for tensile testing. Full-size tubular sections were used as tension test specimen. Based on ASTM A370-03a, for small tubes particularly having $25 \mathrm{~mm}$ diameter and below, and frequently for larger sizes, it is standard practice to use the full-size tubular section for test, unless there are limited with machine restrictions. The length of the tube must long enough to allow machine to grip the tube without extend beyond the gage length. The gage length for full-size longitudinal test steel tubular specimen is 2 inch or $50 \mathrm{~mm}$, except that having $9.5 \mathrm{~mm}$ diameter or below (ASTM A370-03a). The length required for testing must be over than $156.8 \mathrm{~mm}$ since the diameter of the specimen tubes are $26.7 \mathrm{~mm}$. Empirical mathematical model for ultimate tensile strength was generated using Minitab.

\section{RESULTS AND DISCUSSION}

Ultimate tensile strength in MPa has been recorded for each set of experiment as shown in Table III. Main effect plot as shown in Fig. 3 was used to understand the effect of welding current and jig rotational speed to the tensile strength values. Increase in welding current apparently increases the tensile strength of the welded tubes. Similar trend of results were observed by Serope and Steven [12]. Higher welding current leads to higher depth of penetration thus significant increases the strength of the welded joint [13]-[15]. On the other hand, increasing values of jig rotational speed decreases the tensile strength of the welded tubes. Singh et al. [6] states that the increasing in welding speed resulting the depth of penetration to be decreased. The depth of penetration has significant effect on the strength of welded joints as stated by Robb [14].

TABLE III: Ultimate Tensile STRENGTH (MPA) OF THE ORBITAL WELDED MILD STEEL TUBES WITH DISSIMILAR THICKNESS

\begin{tabular}{|c|c|c|c|c|}
\hline $\begin{array}{c}\text { Std } \\
\text { order }\end{array}$ & $\begin{array}{c}\text { Run } \\
\text { order }\end{array}$ & $\begin{array}{c}\text { Weld } \\
\text { Current (A) }\end{array}$ & $\begin{array}{c}\text { Jig Rotational } \\
\text { Speed (rpm) }\end{array}$ & $\begin{array}{c}\text { Ultimate Tensile } \\
\text { Strength (MPa) }\end{array}$ \\
\hline $\mathbf{2}$ & $\mathbf{1}$ & 80 & 40 & 408.50 \\
\hline $\mathbf{6}$ & $\mathbf{2}$ & 80 & 40 & 412.16 \\
\hline $\mathbf{5}$ & $\mathbf{3}$ & 60 & 40 & 199.71 \\
\hline $\mathbf{8}$ & $\mathbf{4}$ & 80 & 50 & 385.10 \\
\hline $\mathbf{7}$ & $\mathbf{5}$ & 60 & 50 & 256.42 \\
\hline $\mathbf{3}$ & $\mathbf{6}$ & 60 & 50 & 297.76 \\
\hline $\mathbf{1 0}$ & $\mathbf{7}$ & 80 & 40 & 317.59 \\
\hline $\mathbf{9}$ & $\mathbf{8}$ & 60 & 40 & 333.48 \\
\hline $\mathbf{1 2}$ & $\mathbf{9}$ & 80 & 50 & 337.83 \\
\hline $\mathbf{1}$ & $\mathbf{1 0}$ & 60 & 40 & 318.29 \\
\hline $\mathbf{1 1}$ & $\mathbf{1 1}$ & 60 & 50 & 260.03 \\
\hline $\mathbf{4}$ & $\mathbf{1 2}$ & 80 & 50 & 317.42 \\
\hline
\end{tabular}

Based on the Pareto Chart of the Standardized Effects in Fig. 4, welding current is the most influential factor as compared to the jig rotational speed. Abbasi et al. [16] states that welding current is the most significant parameter for welding as it control the depth penetration of welding as well 
as the fusion depth, the burn rate of electrode and also the weld geometry.

Response Optimizer in Minitab was to determine the best factors in which to optimize the response. The goal is to maximize the response. Five solutions were listed and the solution with the nearest composite desirability to 1.000000 is better. The best set of parameter to get maximum tensile strength is $80 \mathrm{~A}$ welding current and $50 \mathrm{rpm}$ jig rotational speed.

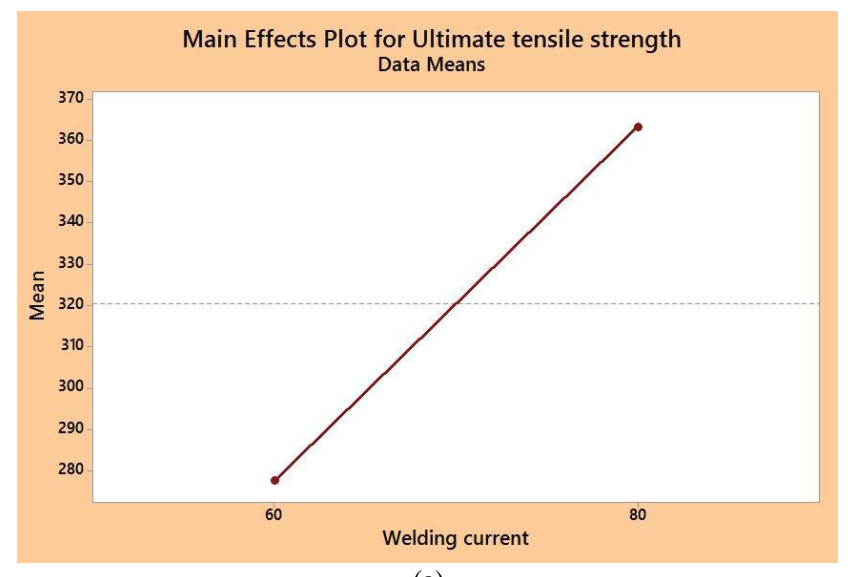

(a)

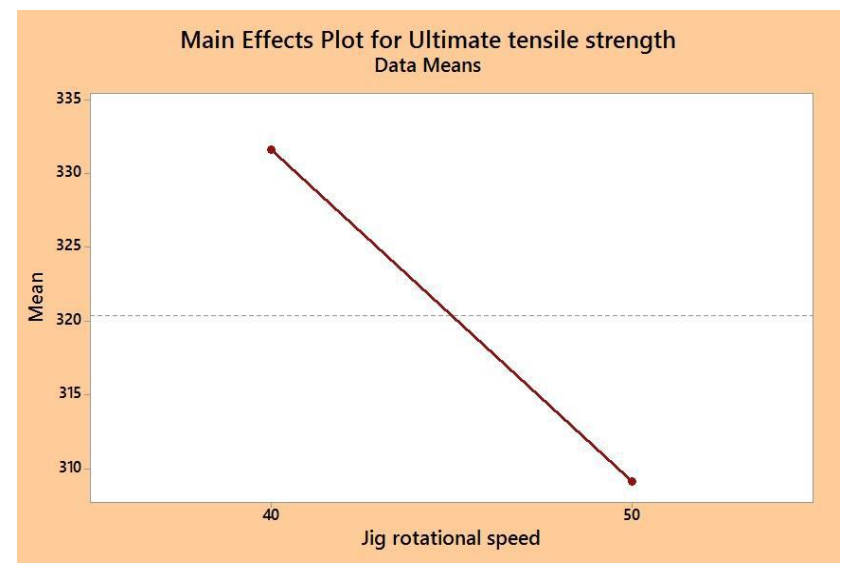

(b)

Fig. 3. Effect Plot of (a) welding current and (b) jig rotational speed against the ultimate tensile strength of the weldment.

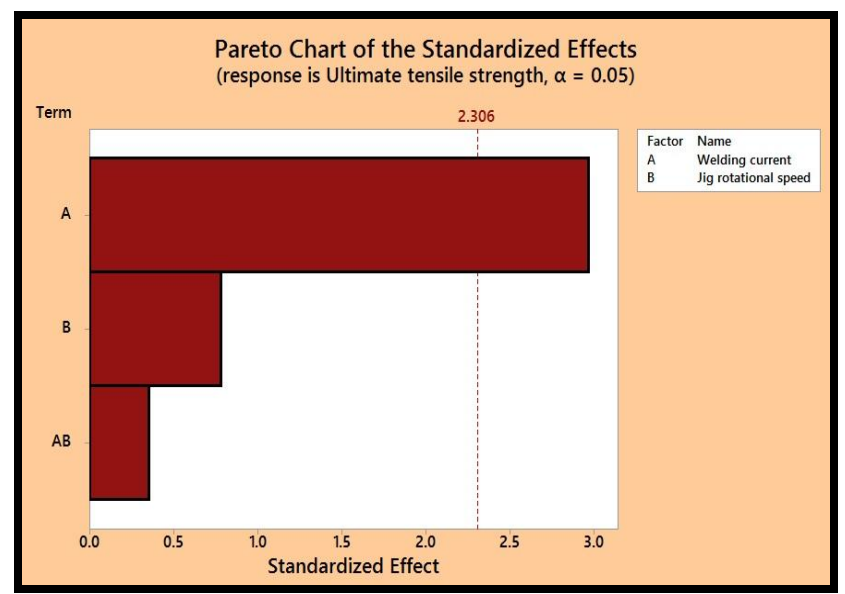

Fig. 4. Pareto Chart of the Standardized Effects for the ultimate tensile strength of the weldment.

Minitab calculated the empirical mathematical model for the response. The equations represent the relation between the factors; as the selected values, and response; as the observed values, which permits the prediction of the most probable values of the response. Empirical mathematical model for the ultimate tensile strength is shown in Eq. 1. Verification of the model was performed and it shows high accuracy of $96.8 \%$ (refer to Table IV).

Ultimate tensile strength $=-196+8.8$ (welding current $)+4.8$ (jig rotational speed) -0.101 (welding surrent) (jig rotational speed)

TABLE IV: EMPIRICAL VALUES VERSUS ACTUAL VALUES

\begin{tabular}{|c|c|c|c|}
\hline Factors & $\begin{array}{c}\text { Weld } \\
\text { Current (A) }\end{array}$ & $\begin{array}{c}\text { Jig Rotational } \\
\text { Speed (rpm) }\end{array}$ & $\begin{array}{c}\text { Ultimate Tensile } \\
\text { Strength (MPa) }\end{array}$ \\
\hline $\begin{array}{c}\text { Empirical } \\
\text { Value }\end{array}$ & 80 & 40 & 376.80 \\
\hline $\begin{array}{c}\text { Actual } \\
\text { Value }\end{array}$ & 80 & 40 & 389.42 \\
\hline $\begin{array}{c}\text { Accuracy } \\
(\%)\end{array}$ & & & 96.8 \\
\hline
\end{tabular}

\section{CONCLUSION}

It can be concluded that, tensile strength of the welded tubes increase with increasing of welding current between 60 and $80 \mathrm{~A}$ due to deeper penetration which leads stronger weld joint. On the other hand, increasing in jig rotational speed between 40 and $50 \mathrm{rpm}$ decreases the tensile properties of the welded tubes due to decreases in penetration which resulting weaker weld joint. This study also indicates that welding current is the most significant parameter which influenced tensile properties of welded mild steel tubes by MIG orbital welding compared to jig rotational speed. The optimum parameter setting to get the maximum tensile strength for this study was 80 A welding current and $40 \mathrm{rpm}$ jig rotational speed. The mathematical empirical model was developed and verified. Accuracy of the model was $96.8 \%$.

\section{ACKNOWLEDGMENT}

N. I. S. Hussein, M. N. Ayof and S. Nordin thank the Faculty of Manufacturing Engineering, Universiti Teknikal Malaysia Melaka for providing the facilities throughout this research work and the Ministry of Education Malaysia for the financial support.

\section{REFERENCES}

[1] ThyssenKrupp. (Feb. 2010). Customize solution with Tailored Orbitals: New production process extends possibilities for eco-friendly use of stainless steel in car exhaust systems. [Online]. Available: http://www.thyssenkrupp.com/en/presse/art_detail.html\&device=prin ter\&eid=TKBase_1264760725661_943879168

[2] WISCO Tailored Blanks, "Methods for producing tailored strips," EP 2364236 B1, August 13, 2014.

[3] Thyssen Krupp Materials UK. (May 2010). Dedicated laser welding line for orbitals. [Online]. Available: http://www.tubefirst.com/newsdetail.php?ID=2919

[4] N. Arunkumar, P. Duraisamy, and S. Veeramanikandan, "Evaluation of mechanical properties of dissimilar metal tube welded joints using inert gas welding," International Journal of Engineering Research and Applications (IJERA), vol. 2, no. 5, pp. 1709-1717, 2012.

[5] J. O. Olawale, S. A. Ibitoye, K. M. Oluwasegun, M. D. Shittu, and C. Ofoezie, "Correlation between process variables in shielded metal-arc welding (SMAW) process and post weld heat treatment (PWHT) on some mechanical properties of low carbon steel welds," Journal of Minerals and Materials Characterization and Engineering, vol. 11, pp. 891-895, 2012. 
[6] R. P. Singh, R. C. Gupta, and S.C. Sarkar, "The effect of process parameters on penetration in shielded metal arc welding under magnetic field using artificial neural networks," International Journal of Application or Innovation in Engineering and Management, vol. 1, no. $4,2012$.

[7] L. Lian, "The effect of process parameters on penetration in gas metal arc welding," Master thesis, Faculty of Manufacturing Engineering, Universiti Teknikal Melaka Malaysia, 2012.

[8] E. Karadeniz, U. Ozsarac, and C. Yildiz, "The effect of process parameters on penetration in gas metal arc welding processes," Journal of Material and Design, vol. 28, pp. 649-656, 2007.

[9] A. R. Bahman and E. Alialhosseini, "Change in hardness, yield strength and UTS of welded joints produced in St37 grade steel," Indian Journal of Science and Technology, vol. 3, pp. 1162-1164, December 2010.

[10] M. Alenius, P. Pohjanne, M. Somervuori, and H. Hanninen, "Exploring the mechanical properties of spot welded dissimilar joints for stainless and galvanized steels," Welding Journal, vol. 85, no. 12, pp. 305-313, December 2006.

[11] S. M. Darwish and A. M. Al-Samhan, "Peel and shear strength of spot-welded and weld-bonded dissimilar thickness joint," Journal of Materials Processing Technology, vol. 147, pp. 51-59, March 30, 2004.

[12] K. Serope and R. S. Steven, "Mechanical behavior, testing, and manufacturing properties of materials," Manufacturing, Engineering \& Technology, 5th ed. Upper Saddle River, NJ: Pearson Education, 2006, ch. 2, p. 56.

[13] S. P. Tewari, A. Gupta, and J. Prakash, "Effect of welding parameters on the weldability of material," International Journal of Engineering science and Technology, vol. 2, no. 4, pp. 512-516, 2010.

[14] C. W. Robb, "The effect of weld penetration on the tensile strength of fillet welded joints," Master thesis, Department of Ocean Engineering, Massachusetts Institutes of Technology, 1995.

[15] M. N. Ayof, N. I. S. Hussein, Z. M. Noh, and M. F. M. Pauzi, "Tailored orbital welding of dissimilar stainless steel materials," presented at the Malaysian Technical Universities Conference on Engineering \& Technology (MUCET), Kuantan, Pahang, Dec. 3-4, 2013.

[16] K. Abbasi, S. Alam, and M. I. Khan, "An experimental study on the effect of MIG welding parameters on the weld-bead shape characteristic," Engineering Science and Technology: An International Journal (ESTIJ), vol. 2, no. 4, p. 599, 2012.

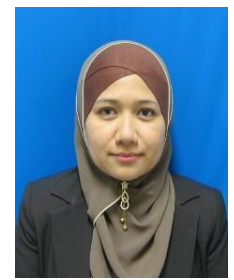

Nur Izan Syahriah Hussein was born on September 14, 1977, in Johore Bahru, Johore, Malaysia. She graduated with her bachelor of engineering degree in manufacturing engineering in 2001 from the International Islamic University of Malaysia (IIUM) She got her master of science degree in manufacturing systems engineering in 2004 from University of Warwick, United Kingdom, with thesis titled "Direct Metal Deposition of Waspaloy," she received her $\mathrm{PhD}$ degree in 2010 from University of Nottingham, United Kingdom. She is also a member of Board of Engineers Malaysia, Institute of Materials Malaysia and Malaysia Society for Engineering and Technology

She is currently a senior lecturer in the Faculty of Manufacturing Engineering, Universiti Teknikal Malaysia Melaka. One of her article was published in 2008 in Materials Science and Engineering, A497, pp. 260-269, entitled "Microstructure formation in waspaloy multilayaer builds following direct metal deposition with laser and wire." She also wrote a chapter entitled "9\% nickel steels and their welding behavior in comprehensive materials processing" which was published in 2014. She is actively involved in research in which related to welding technology and laser material processing.

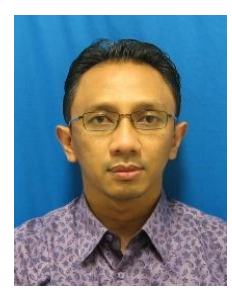

Mohamad Nizam bin Ayof was born on April 14, 1976 in Batu Pahat, Johore, Malaysia. He received his bachelor degree in physics with majoring field of industrial physics in 2000 from the Malaysia Technology University (UTM). He obtained his master of science degree by research in laser cavitation in 2002 from UTM. He is currently a senior lecturer in the Faculty of Manufacturing Engineering, Universiti Teknikal Malaysia Melaka. He is actively involved in research which related to welding technology and non-destructive testing.

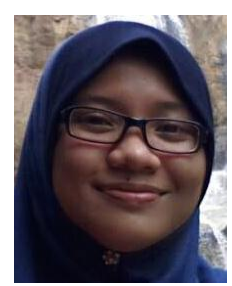

Nor Safura Nordin received her master degree in manufacturing engineering (manufacturing system engineering) in 2014 from Universiti Teknikal Malaysia Melaka. She wrote a master dissertation entitled "Effect of welding parameters to the tensile properties of tailor orbital welded mild steel tubes with dissimilar thickness." She is currently pursuing her postgraduate study in the Universiti Teknikal Malaysia Melaka in a research in which related to 



\section{Measurement Control Engineering and Mechatronics}


